\title{
THE EFFECTS OF CONTAMINATION OF CALCAREOUS SEDIMENTS ON THEIR RADIOCARBON AGES
}

\author{
DUŠAN SRDOČ, NADA HORVATINČIĆ, BOGOMIL OBELIĆ, \\ INES KRAJCAR-BRONIĆ \\ Rudjer Bošković Institute, POB 1016, YU-41001 Zagreb, Yugoslavia \\ and
}

PEG O'MALLEY

United States Geological Survey, Denver, Colorado

\begin{abstract}
Two principal reasons for the inherent uncertainty in ${ }^{14} \mathrm{C}$ dating of calcareous sediments such as tufa or those of lacustrine origin are the unknown initial ${ }^{14} \mathrm{C}$ activity $\left(\mathrm{A}_{\mathrm{o}}\right)$ of the sediment, mainly affecting younger (Holocene) samples, and contamination of older sediments with recent carbonate, causing ${ }^{14} \mathrm{C}$ ages to be excessively young. To assess the contamination effect, samples of old tufa from the Riss/Würm interglacial were examined. These sediments contain essentially no ${ }^{14} \mathrm{C}$ except that contributed by surface contamination. Tufa samples were crushed and grains ranging in size from $<1 \mathrm{~mm}, 1$ to $2 \mathrm{~mm}$, up to 4 to $5 \mathrm{~mm}$ were separated for analysis; $2 \mathrm{M} \mathrm{HCl}$ was then used to dissolve the samples in successive steps. ${ }^{14} \mathrm{C}$ measurements indicated that each subsequent soluble fraction obtained from porous tufa gave a successively older age, indicating that the surface of the sample was contaminated by younger carbonates. No consistent effect of grain size on the ${ }^{14} \mathrm{C}$ age was observed. Compact tufa proved to be less subject to contamination. ${ }^{14} \mathrm{C}$ ages obtained on this material were also too young, yet older than the age obtained from porous tufa samples.

${ }^{14} \mathrm{C}$ ages of interglacial tufa were cross-checked with the ${ }^{230} \mathrm{Th} /{ }^{234} \mathrm{U}$ dating method, using samples of very clean calcite which overlies the tufa blocks. Inferred ${ }^{230} \mathrm{Th} /{ }^{234} \mathrm{U}$ ages of the interglacial tufa (which had yielded ${ }^{14} \mathrm{C}$ dates ranging from 25,000 to $37,000 \mathrm{yr}$ ) coincided with the last interglacial (Riss/Würm, Stage 5). Samples of Holocene tufa, in which contributions of recent ${ }^{14} \mathrm{C}$ from surface contamination would pose less of a problem, yielded ${ }^{14} \mathrm{C}$ and ${ }^{230} \mathrm{Th} /{ }^{234} \mathrm{U}$ dates which were in excellent agreement.
\end{abstract}

\section{INTRODUCTION}

${ }^{14} \mathrm{C}$ dating of calcareous tufa yields reliable results providing that the tufa was deposited as a result of decomposition of dissolved calcium bicarbonate in cold fresh water. The source of $\mathrm{CO}_{2}$ that dissolves limestone bedrock is biogenic, thus introducing ${ }^{14} \mathrm{C}$ in bicarbonates, and subsequently, in lacustrine sediments. This process is fast in comparison with the half-life of ${ }^{14} \mathrm{C}$, consequently, freshly deposited lacustrine sediments are practically contemporaneous with the surrounding living matter in the biosphere. However, due to the presence of inactive carbon from limestone, the specific activity of lacustrine sediments, as well as that of speleothems, is always lower than the specific activity of living matter. Stoichometrically, ${ }^{14} \mathrm{C}$ activity of dissolved bicarbonates and speleothems should be $50 \%$ of the activity of biogenic $\mathrm{CO}_{2}$. However, numerous measurements have shown that the actual ${ }^{14} \mathrm{C}$ activity of recent freshwater bicarbonates, tufa, and speleothems ranges between $60 \%$ and $90 \%$ of the activity of atmospheric $\mathrm{CO}_{2}$, prior to nuclear weapon tests contamination (Vogel, 1970; Geyh, 1972).

The increase of ${ }^{14} \mathrm{C}$ activity of dissolved bicarbonates in fresh water is caused by an exchange of dissolved $\mathrm{CO}_{2}$ in natural systems of groundwater circulation which are partly or completely open to the atmosphere. The wide range of the resulting ${ }^{14} \mathrm{C}$ activity of the dissolved bicarbonates is the source of a serious error in the ${ }^{14} \mathrm{C}$ age calculation of lacustrine sediments, unless such an activity is measured or estimated fairly precisely. Several 
models for calculation of initial activity of groundwater bicarbonates have been developed (Tamers \& Scharpenseel, 1970; Pearson \& Hanshaw 1970; Mook, 1972; Fontes \& Garnier, 1979; Eichinger, 1983) and comparison of calculated and experimental data are published (Krajcar-Bronic et al, this issue).

A typical error in age estimation of lacustrine sediments due to variability of the initial activity of freshwater bicarbonates ranges from ca 500 to $2500 \mathrm{yr}$. The relative standard deviation may reach unacceptable values for younger (Holocene) sediments $(\mathrm{eg}, 1000 \pm 2500 \mathrm{yr})$, whereas the same absolute error is of the same order of magnitude as the standard deviation of the counting rate of very old samples. Therefore, a realistic assessment or an adequate measurement of the initial activity of sediments is of great importance for younger deposits.

Minor contamination of deposits with recent carbonates (of the order of several percent of total mass of carbonates), will not affect the ${ }^{14} \mathrm{C}$ age of young samples significantly (Olsson, 1980). On the contrary, the same amount of contamination of old deposits with recent carbonates, renders the ${ }^{14} \mathrm{C}$ ages of sediments, the actual age of which is between 20,000 and $40,000 \mathrm{yr}$, quite useless. The same applies to much older sediments; in this case the contamination with recent carbonates produces ${ }^{14} \mathrm{C}$ ages within the range of the method (eg, $<40,000 \mathrm{yr})$, whereas the actual age is beyond the limits of the ${ }^{14} \mathrm{C}$ method, as revealed by the ${ }^{230} \mathrm{Th} /{ }^{234} \mathrm{U}$ method. In fact, the inconsistency of ${ }^{14} \mathrm{C}$ ages of samples of old tufa taken from the same block, as well as the incompatibility of obtained ages with paleoclimatic conditions, prompted a more detailed study which is presented below.

\section{EXPERIMENTAL}

\section{Radiocarbon Dating of Old Tufa Deposits}

Tufa samples were selected from outcroppings or huge blocks which belonged to an interglacial phase of tufa growth in the Plitvice National Park, NW Yugoslavia. ${ }^{14} \mathrm{C}$ dates of numerous samples were very inconsistent (Srdoč et al, 1980) ranging in age from ca 20,000 to 40,000 yr BP. Samples of calcite in the form of clean crystals that sporadically overlay the tufa blocks always gave the background counting rate, $i e$, their age was much older than the lowest detectable ${ }^{14} \mathrm{C}$ age. These factors point to contamination of very old, porous tufa layers with young carbonate as the possible explanation for inconsistent ${ }^{14} \mathrm{C}$ ages.

Experimental verification of the contamination of old deposits was based on the assumption that the surface layer which may contain the contaminant will dissolve first, when a sample of calcareous tufa is treated with diluted hydrochloric acid. Two samples of old tufa were chosen for chemical treatment with acid. The porous, spongy, structured samples were considered more susceptible to contamination, whereas compact tufa seemed less affected by contamination. Samples of tufa weighing ca $300 \mathrm{~g}$ were crushed and separated into fine ( $<1 \mathrm{~mm}$ in diameter), medium (1 to $2 \mathrm{~mm})$, and coarse grains $(4$ to $5 \mathrm{~mm}$ ). It was expected that this procedure could result in a difference in activity of evolved $\mathrm{CO}_{2}$ by varying the ratio of 
freshly cut surface and the contaminated one. However, the activity of evolved $\mathrm{CO}_{2}$ was much more dependent on the degree of etching the grains than on the grain size; therefore, no particular grain size could be specified as the most contaminated or as the cleanest one.

Dissolution of tufa samples was carried out in 2 or 3 steps (depending on the sample size), each step producing the amount of $\mathrm{CO}_{2}$ sufficient to fill the gas processing system which converts the evolved $\mathrm{CO}_{2}$ into methane. The amount of $2.0 \mathrm{M} \mathrm{HCl}$, sufficient to dissolve the whole sample, was divided in 2 or 3 portions and slowly dripped on the sample, which was constantly stirred in the reaction flask. The evolved $\mathrm{CO}_{2}$ was removed from the reaction flask in a stream of nitrogen and trapped at liquid nitrogen temperature. Subsequent chemical and counting procedures are described elsewhere (Srdoč, Breyer \& Sliepčević, 1971; Srdoč et al, 1979, 1982).

The results of succesive dissolution of porous and of compact tufa are presented in Table 1. For comparison, the result of ${ }^{14} \mathrm{C}$ dating clean calcite crystalline aggregate is also given.

$$
{ }^{230} \mathrm{Th} /{ }^{234} \mathrm{U} \text { Dating of Old Tufa }
$$

${ }^{14} \mathrm{C}$ dates of old tufa (Table 1) showed clearly that the true age of old tufa lies beyond the limits of ${ }^{14} \mathrm{C}$ dating. We also used the ${ }^{230} \mathrm{Th} /{ }^{234} \mathrm{U}$ dating method on clean calcite which can be found overlying tufa blocks as well as on porous tufa. First, a clean Holocene calcite sample was split into two halves and dated using both methods. The agreement between the obtained dates was excellent $\left(1440 \pm 150{ }^{14} \mathrm{C}\right.$ yr ws $1400 \pm 600{ }^{230} \mathrm{Th} /{ }^{234} \mathrm{U}$ yr $)$. The

TABLE 1

The activity in percent modern and the apparent ${ }^{14} \mathrm{C}$ age of successive fractions obtained by fractional dissolution of old tufa samples from Plitvice National Park, Yugoslavia

\begin{tabular}{|c|c|c|c|}
\hline $\begin{array}{l}\text { Grain size } \\
(\mathrm{mm})\end{array}$ & $\begin{array}{l}\text { No. of } \\
\text { fraction* }\end{array}$ & $\begin{array}{c}\% \\
\operatorname{modern} * *\end{array}$ & $\begin{array}{c}\text { Apparent }{ }^{14} \mathrm{C} \text { age } \\
\text { (in yr BP) } \dagger\end{array}$ \\
\hline \multicolumn{4}{|c|}{ Porous tufa } \\
\hline $\begin{array}{l}4-5 \\
4-5 \\
4-5 \\
1-2 \\
1-2 \\
<1 \\
<1\end{array}$ & $\begin{array}{r}\text { I }(30 \%) \\
\text { II }(30 \%) \\
\text { II }(30 \%) \\
\text { I }(50 \%) \\
\text { II }(50 \%) \\
\text { I }(50 \%) \\
\text { II }(50 \%)\end{array}$ & $\begin{array}{r}12.2 \pm 1.0 \\
5.9 \pm 1.1 \\
3.9 \pm 0.7 \\
7.8 \pm 0.8 \\
1.7 \pm 0.7 \\
10.8 \pm 0.9 \\
3.6 \pm 0.7\end{array}$ & $\begin{array}{l}15,000 \pm 400 \\
21,100 \pm 800 \\
24,500 \pm 1200 \\
18,700 \pm 1600 \\
31,000 \pm 400 \\
16,000 \pm 400 \\
25,000 \pm 1200\end{array}$ \\
\hline \multicolumn{4}{|c|}{ Compact tufa } \\
\hline $\begin{array}{l}1-5 \\
1-5 \\
1-5\end{array}$ & $\begin{array}{r}\text { I }(30 \%) \\
\text { II }(30 \%) \\
\text { III }(30 \%)\end{array}$ & $\begin{array}{l}3.9 \pm 0.3 \\
2.9 \pm 0.3 \\
1.0 \pm 0.3\end{array}$ & $\begin{array}{c}24,400 \pm 1100 \\
26,900 \pm 1600 \\
>37,000\end{array}$ \\
\hline \multicolumn{4}{|c|}{ Clean calcite crystalline aggregate } \\
\hline $4-5$ & I $(100 \%)$ & $0.5 \pm 0.6$ & $>37,000$ \\
\hline
\end{tabular}


same procedure was applied to several old tufa samples with ${ }^{14} \mathrm{C}$ ages that fell within the last glaciation period and which were not considered reliable. The ${ }^{230} \mathrm{Th} /{ }^{234} \mathrm{U}$ dates of clean calcite overlying tufa blocks coincided with the last interglacial (Riss/Würm, Stage 5), as opposed to ages obtained on porous tufa, which were not acceptable due to contamination with clay containing thorium. The ${ }^{230} \mathrm{Th} /{ }^{234} \mathrm{U}$ age of clean calcite, $119,000 \pm 8500 \mathrm{yr}$, fits very well in the time sequence of tufa deposition based on the fact that a warm and humid climate is required for tufa growth.

\section{CONCLUSIONS}

${ }^{14} \mathrm{C}$ dating of Holocene calcareous sediments, such as lake sediments or tufa poses no problem since a small percentage of younger calcite does not affect their ${ }^{14} \mathrm{C}$ age appreciably. Moreover, the requested precision of tufa dating is usually much lower than that of archaeologic samples. However, in case of old, preglacial tufa, minor contamination with recent carbonate results in a false, unacceptable age. For example, most of the porous samples of old tufa collected in the karst region of the Plitvice National Park, Yugoslavia, showed an apparent ${ }^{14} \mathrm{C}$ age 20,000 to 40,000 $\mathrm{yr}$. This age would place the formation of tufa in Europe during the Würm glacial, which is unacceptable.

Porous tufa turned out to be contaminated with ${ }^{230} \mathrm{Th}$, and thus was unreliable for ${ }^{230} \mathrm{Th} /{ }^{234} \mathrm{U}$ dating. However, clean calcite crystal aggregates that frequently intersperse tufa formation, or overlie tufa blocks, yield reliable and reproducible data. The ${ }^{230} \mathrm{Th} /{ }^{234} \mathrm{U}$ data presented here were crosschecked at the Niedersächsisches Landesamt für Bodenforschung, Hannover, West Germany. ${ }^{230} \mathrm{Th} /{ }^{234} \mathrm{U}$ dates obtained on calcite aggregates at USGS and NLfB laboratories are in excellent agreement (Horvatinčić, ms). ${ }^{230} \mathrm{Th} /{ }^{234} \mathrm{U}$ dates of tufa deposits in the Plitvice National Park coincide with the warm and humid Riss/Würm interglacial. This is quite plausible on the basis of present knowledge about climatic conditions that favor tufa formation.

\section{REFERENCES}

Eichinger, L, 1983, A contribution to the interpretation of ${ }^{14} \mathrm{C}$ groundwater ages considering the example of a partially confined sandstone aquifer, in Stuiver, M and Kra, R S, Internatl ${ }^{14} \mathrm{C}$ conf, 11 th, Proc: Radiocarbon, v 25, no. 2, p 347-356.

Fontes, J Ch and Garnier J M, 1979, Determination of the initial ${ }^{14} \mathrm{C}$ activity of the total dissolved carbon: Water Resources Research, v 15, p 399-413.

Geyh, M A, 1972, On the determination of the initial ${ }^{14} \mathrm{C}$ content in groundwater, in Rafter, $\mathrm{T} \mathrm{A}$ and Grant-Taylor, T, eds, Internatl ${ }^{14} \mathrm{C}$ conf, 8 th, Proc: Royal Soc New Zealand, Wellington, p D58-D69.

Horvatinčić, N, (ms), 1985, Radiocarbon age measurements of tufa deposits from Plitvice lakes area (in Croatian with English summary); Ph D dissert, Univ Zagreb.

Krajcar-Bronić, I, Horvatinčić, N, Srdoč, D and Obelić, B, 1986 , On the initial ${ }^{14} \mathrm{C}$ activity in karst aquifers with short mean residence time, in Stuiver, M and Kra, RS, eds, Internatl ${ }^{14} \mathrm{C}$ conf, 12 th, Proc: Radiocarbon, this issue.

Mook, W G, 1972, On the reconstruction of the initial ${ }^{14} \mathrm{C}$ content of groundwater from the chemical and isotopic composition, in Rafter, T A and Grant-Taylor, T, eds, Internatl ${ }^{14} \mathrm{C}$ conf, 8th, Proc: Royal Soc New Zealand, Wellington, p 343-352.

Olsson, I, 1980, Progress in radiocarbon dating, promising techniques and trends in the research: Fizika, v 12 suppl 2, p 37-68.

Pearson, F J and Hanshaw, B B, 1970, Sources of dissolved carbonate species in groundwater and their effects on C-14 dating, in Symposium on isotope hydrology, Proc: IAEA, Vienna, p 271-285. 


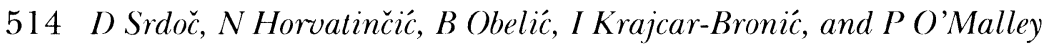

Srdoč, D, Breyer, B and Sliepčević, A, 1971, Rudjer Bošković Institute radiocarbon measurements I: Radiocarbon, v 13, p $135-140$.

Srdoč, D, Horvatinčić, N, Obelić, B and Sliepčević, A, 1980, Radiocarbon dating of calcareous tufa; how reliable data can we expect? in Stuiver, $M$ and $\mathrm{Kra}, \mathrm{RS}$, eds, Internat ${ }^{14} \mathrm{C}$ conf, 10th, Proc: Radiocarbon, v 22, no. 3, p 858-862.

1982, Rudjer Boskovic Institute radiocarbon measurements VII: Radiocarbon, v 24, p 325-371.

Srdoč, D, Sliepčević, A, Obelić, B and Horvatinčić, N, 1979, Rudjer Boskovic Institute radiocarbon measurements V: Radiocarbon, v 21, p 131-137.

Tamers, M A and Scharpenseel, H W, 1970, Sequential sampling of radiocarbon in groundwater, in Symposium on isotope hydrology, Proc: IAEA, Vienna, p 241-257.

Vogel, J C, 1970, Carbon-14 dating of groundwater, in Symposium on isotope hydrology, Proc: IAEA, Vienna, p 225-239. 